\title{
GEOLOGY, MINERALOGY AND RADIOELEMENTS POTENTIALIYY OF MICROGRANITE DIKES TO THE SOUTH OF WADI ABU HADIEDA AREA, NORTHERN EASTERN DESERT, EGYPT.
}

\author{
Ali A. Omran* \\ * Nuclear Materials Authority, Cairo, Egypt,
}

\begin{abstract}
The granite dike swarms intruding the older granitiod and occasionally the younger gabbros were emplaced through a shear zone extending in NE-SW direction. These dikes are composed mainly from alkali feldspar granites. They are fine grained, hard and compact vary in color from pink, red, reddish brown and occasionally bloody red. It is affected by varying degrees of alterations and subjected to deformation processes. Mineral segregations and pegmatite pockets are encountered along deformed and altered zones. Alkali feldspars mainly perthites and microcline, quartz, little sodic plagioclase and biotite represent the main rock forming minerals. These dikes possess high contents of radioelements especially thorium. The eTh contents range from $63.9 \mathrm{ppm}$ to $2523 \mathrm{ppm}$ with an average $465.8 \mathrm{ppm}$ where the eU content range from $25 \mathrm{ppm}$ to $497.9 \mathrm{ppm}$ with $106.3 \mathrm{ppm}$ average. The mineral segregations give the highest level of $\mathrm{U}$ and eTh contents reach up to 7331 ppm and 1386 ppm respectively. Secondary uranium minerals (uranophane and curite), thorium minerals (thorite) and $U$ - and Th-bearing minerals (Zircon, allanite, columbite, samarskite, xenotime, monazite, kasolite and titanite) are identified. Other non radioactive minerals such as magnetite, goetite, hematite, cronstedtite, pyrite, fluorite, garnet are also identified. Also, chemical analyses $(X R F)$ revealed presence of high concentration of $U, Z r, Y, N b, B a, Z n, R b$ and $S r$ in addition to presence of $\mathrm{V}, \mathrm{Pb}, \mathrm{Ni}$ and $\mathrm{Cr}$. Au and Pt are also present.
\end{abstract}

Keywards: Radioelements, mineralogy, Granite dike, Abu Hadieda, Northeastern Desert

\section{INTRODUCTION}

Uranium and thorium are generally enriched in the youngest, most felsic and most potassic members of comagmatic suites of igneous rocks (Rogers and Adams, 1969). Most of radioactive occurrences in the basement rocks of Egypt are in the granites and associated pegmatites. The high radioactivity level of these rocks is attributed to the presence of accessory minerals e.g. zircon, monazite, thorite, uranothorite and allanite (Shurmann, 1966). The present work deals with highly radioactive microgranite dikes encountered at wadi (W.) Abu Hadieda area.

Wadi Abu Hadieda area is located in the Northern Eastern Desert of Egypt at, about 20 $\mathrm{km}$ westward from Safaga City at the Red Sea coast. The area can be easily accessed via a newly established part of Qena - Safaga asphaltic road, along W. Barud Al Abyad, which runs directly to the north of the area. The region has an area of $26.1 \mathrm{~km}^{2}$ bounded by latitudes $26^{\circ} 4254$ and $26^{\circ} 45^{\circ} 36^{\square} \mathrm{N}$ and longitudes $33^{\circ}$ $44^{\circ} 06^{\square}$ and $33^{\circ} 47^{-} 42^{\square}$ E (Fig. 1).

There are few detailed investigations combined with radiometric and mineralogical studies carried out on the area of study (e.g. Omran,
2005 \& El Hadary et al, 2015). The high radioactivity level related to the microgranite dikes in this area has been discovered for the first time by the author in 2005.

The aim of the present study is to outline the field concept, petrographic, radiometric and mineralogical characteristics which affect on the distribution of uranium and thorium occurrences associated with the granite dikes. To verify this aim, the dikes were carefully studied and detailed geologic map was constructed. Also, detailed petrographical, radiometrical and mineralogical studies in addition to trace element distribution were carried out on the granite dikes.

\section{GEOLOGIC SETTING}

The studied area is occupied with Precambrian basement suites comprise older granitoids, younger gabbros and younger granites which injected with basic and acidic dikes of different attitudes. The outcrops of the different rock units are traversed by many valleys filled with alluvial deposits of Quaternary age. According to Omran 2005, the older granitoids range in compostion from granodiorite to quartz diorite through tonalite, the younger gabbros are olivine, pyrox- 


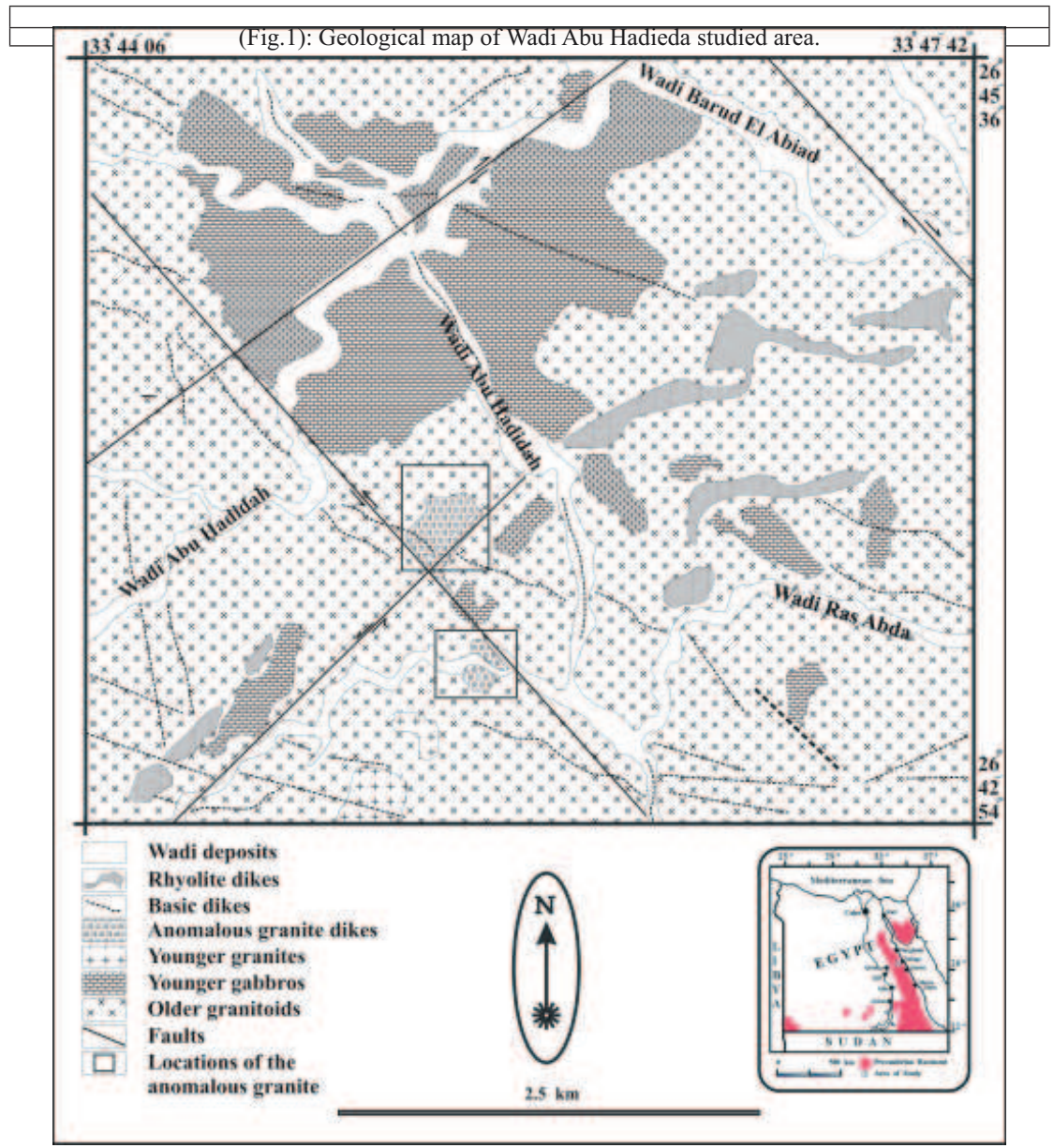

ene gabbros and the younger granites range in composition from syenogranites to alkali feldspar granites.

The basic dikes are the oldest and the prevalent ones. They are most widespread and concentrated in the southern and western parts. They are mainly basaltic in composition and trend in NNW, WNW, NW, NE, E-W and N$S$ directions with decreasing order of abundance. The basic dikes are intersected with acidic ones (rhyolites).

The acidic dikes are the less in number and the largest in terms of size and space compared to the basic ones. They are mainly represented by rhyolites, and microgranite dikes. They encountered at the northeastern part and extend to the southwestern part of the area. Also, the rhyolite dikes occupy the middle area and extend from the extreme southwest to the northeast. They form high and huge blocks, with irregular shapes, reach up to more than 100 meters width and extend for more than $3.5 \mathrm{~km}$ in NE-SW direction.
The microgranite dikes occur as swarms of abnormal radioactivity and poly mineralization. They are restricted to a highly deformed, faulted, and sheared narrow zone, up to $300 \mathrm{~m}$ width and extends for more than $1.5 \mathrm{~km}$ in NE to NNE directions. The zone has been split into two parts under the action of a NW-SE left lateral strikeslipe fault (Fig.1). These two parts are illustrated in detail in figures 2 and 3.

The microgranite dikes occur as vertical walls and/or elongated elliptical-shaped bodies, with outcrop dimensions range from few meters to hundred meters in length and from less than a meter up to tens of meters in width. They are emplaced dominantly into the older granitoids rocks (Fig. 4a) and occasionally into the younger granites and the younger gabbros. Generally, the dykes show an intrusive relationship with the older granitoids and their orientation and situation indicates that the forming melts migrated along pre-existing structures during their ascent. Individual microgranite dykes generally strike NE-SW, which is approximately compatible, with the trend of predominating structure. On 


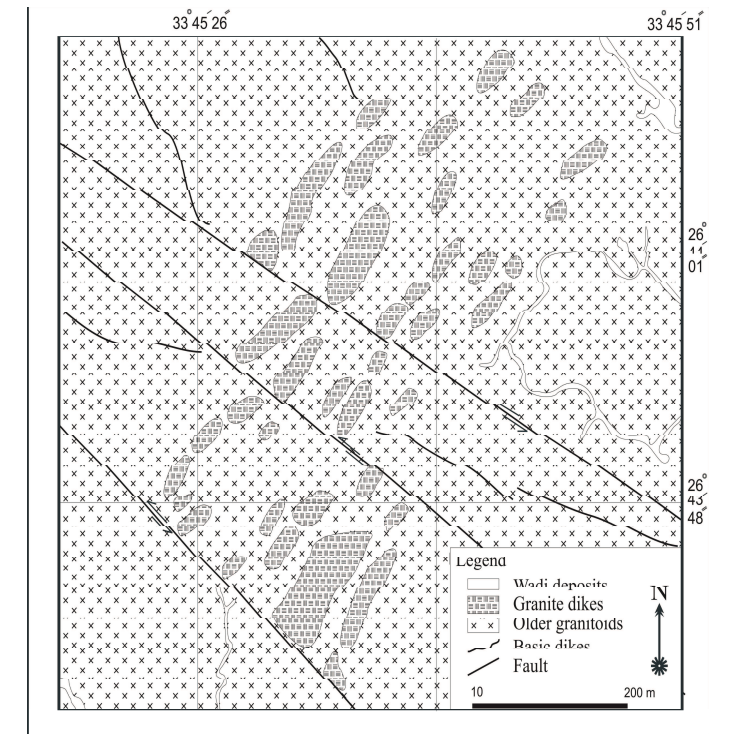

(Fig.2): Geological map of the southern area of the microgranite dikes

the other hand, the dike rocks are affected with high deformation processes led to intense joints and fractures accompanied with alterations.

The micrgranite dikes are equigranular, fine grained rocks, compact and silicified in some areas. They show color varying from buff, pink, dark red and brown. Various hydrothermal alteration processes such as hematitization, silicification, kaolinization and episyenitization (Fig.4b) are affecting on the rocks with different degrees of intense. The hematitization process is the most common and the most influential and always exists and increases in the fractured zones accompanied with high uranium and thorium mineralizations due to the high ability of iron oxides for uranium adsorption from its bearing solutions (Hussein et al. 1965). Dawson (1956) suggested that iron and uranium are geochemically related and the ferric oxide is abundantly found with uranium. He also referred to the staining feature of the secondary uranium minerals due to ferric oxide. Kamineni et al. (1986), Casas et al. (1994) and Drot et al. (2007) had documented sorption of the uranyl ion on iron oxides and montmorillonite.

The microgranite dikes posses a number of highly ferruginated, highly radioactive and highly fractured mineral segregation with black, browinish black and riddish brown color (Fig. $4 c)$. They are of irregular shape reach up to $0.5 \times 1 \mathrm{~m}$ in size confined to shear and fault planes

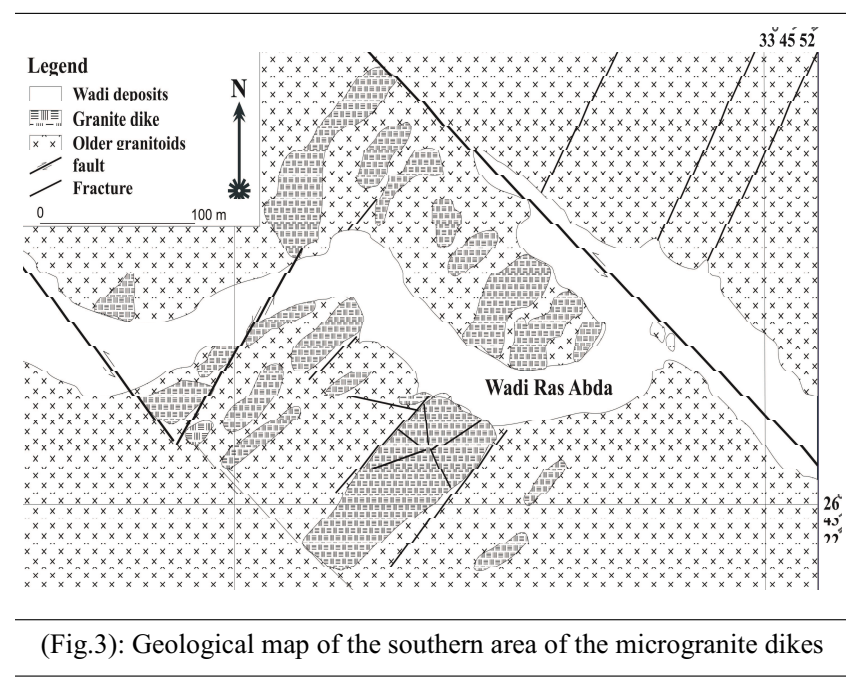

at the contact area and occur as fracture filling on the walls of dikes. On the other hand, irregularshaped pegmatite pockets and bodies generally not wider than one meter are also encountered especially along or near the contact with the shear zone (Fig.4d). These pegmatites are of unzoned type and show low level of radioactivity.

Faults represent the main structural features in the study areas. The NE and NW trends comprise both left-lateral and right lateral strike-slip faults (Fig. 1). The NW-trending faults are the oldest fracture planes, followed by the NE orientations. On the other hand the area is dissected by joints generally trending in the $\mathrm{N} 20^{\circ} \mathrm{W}$ and N70"E directions.

\section{PETROGRAPHY}

Petrographically, the microgranite dikes are fine grained alkali feldspars granite with equigranular texture. It is composed mainly of alkali feldspar mainly microcline- and orthoclase- perthites in addition to micocline (65-68\%), quartz (25-35\%) and minor sodic plagioclase (0-10\%). Biotite is scarce. Iron oxides, zircon, pyrite, thorite, samaskite, allanite, curite, columbite, xenotime, monazite, kasolite, uranophene, flaurite, titanite, apatite and ilmenite represent the main accessories.

Cathelineau and Poty (1989) and Banks et al. (1994), among others, believe that accessory minerals, such as monazite, uranophane, zircon and apatite, are possible sources of high concentration of REE, as well as U. The altered zones show several types of alteration, such as silicifica- 


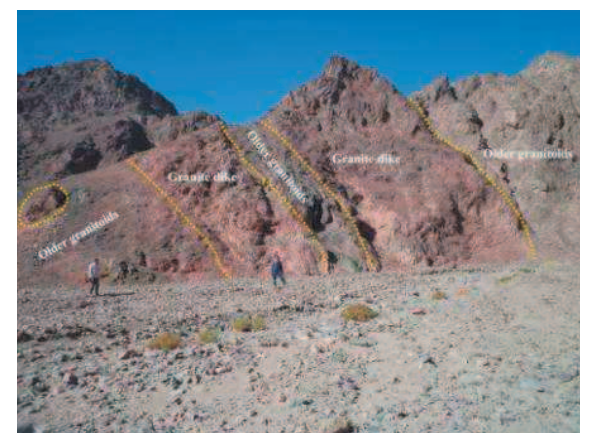

(Fig. 4a): granite dikes intersect older granitoids, looking southwest

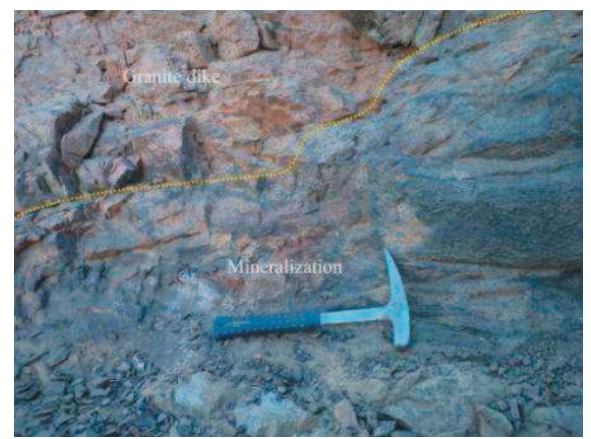

(Fig. 4c): close up view of mineralization in granite dikes, looking southeast

tion, hematization and sericitization. Dissolution of quartz (episyenitization) is also a conspicuous alteration feature. The vugs left after the dissolution of quartz are filled with microcrystalline silica, fluorite, kaolinite, and sometimes secondary uranium minerals.

The alkali feldspars occur as subhedral to anhedral crystals of perthites and microcline. The perthite crystals usually enclose quartz grains and occasionally plagioclase crystals (Fig. 5a), show signs of weak brecciation and fine granulation and intersected by thin veinlets of muscovite. The microcline presents as minute intergranular crystals most probably developed due to a phase of K-metasomatism. Alkali feldspar is partially altered to sericite and muscovite and stained with iron oxides.

Quartz occurs as subhedral to anhedral crystals often showing wavy and undulose extinctions. The deformed quartz contains secondary radioactive minerals and iron oxides as fracture fillings. Inclusions of drop-like quartz are also very common in the alkali feldspar megacrysts. Occasionally, the quartz occurs as monocrystalline aggregates with abundant embayement features (figs. 5a-g).

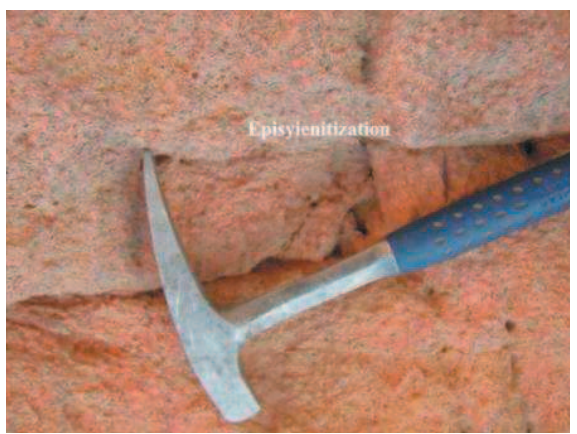

(Fig. 4b): close up view of episyenitization in granite dikes, looking southwest

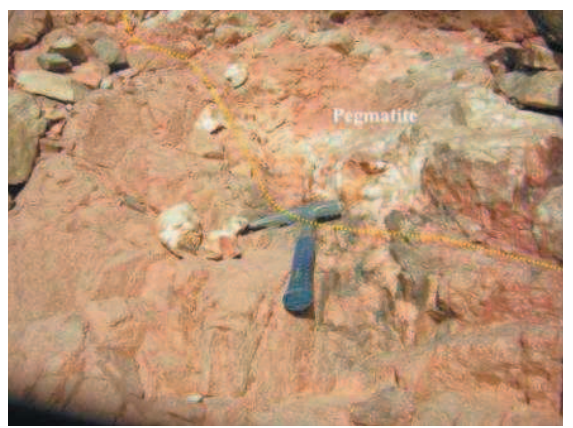

(Fig.4d): close up view of unzoned pegmatite in granite dikes, looking southeast

Plagioclase occurs as subhedral to euhedral crystals show normal to oscillatory zoning, which is well marked by saussuritization in the An-rich zones. Some crystals are irregular and show embayed rims in contact with alkali feldspar grains (figs. 5a-e). Many very fine crystals are enclosed by alkali feldspar megacrysts.

Uranophane occurs as fracture filling in quartz and opaques mixed with iron oxides referring to epigenetic origin (Figs.5b\&c). Also it occurs as clusters of radiating tiny yellow to greenish yellow needles lining crevices (Fig.5f). Allanite has a euhedral habit showing color zoning associating uranophane and opaques (Fig.5c). It also occurs as reaction rims on monazite (Fig.5d). Curite occurs as orangish red minute crystals associating uranophane and opaues (Fig.5b). kasolite occurs as euhedral crystal of prismatic form with reddih orange color (Fig.5e). Zircon occurs as well formed-crystals mostly included in the feldspars and occasionally in secondary fluorite (Fig.5g). Some crystals are characterized by sieve texture due to uranophane and thorite inclusions especially in mineralized samples which are highly charged with mitamict zircon (Fig.5h). Xenotime occurs as bluewish brown, greenish 


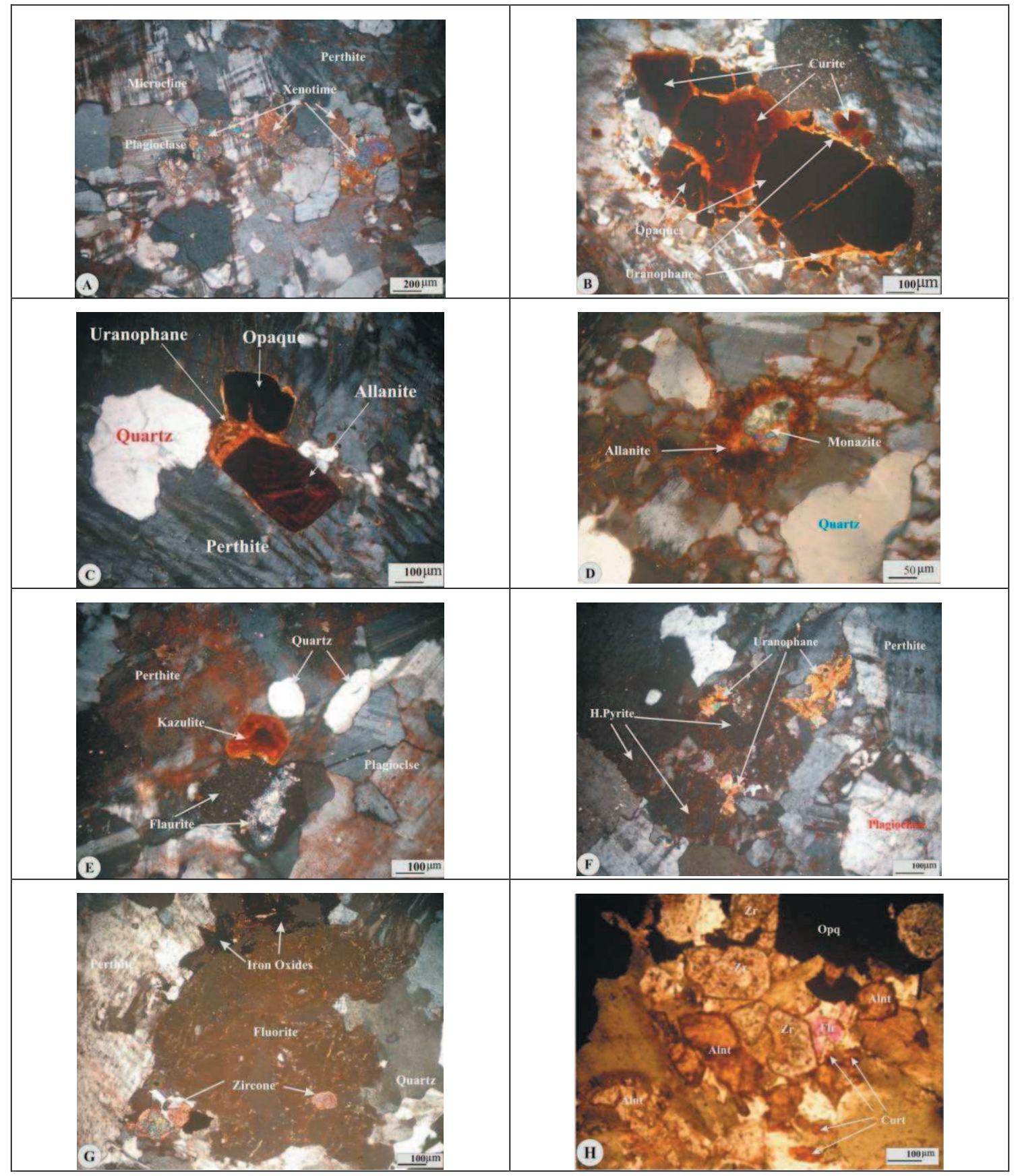

(Fig.5a): Subhedral to anhedral crystals of microcline and perthite enclose plagioclase, xenotme and quartz

(Fig.5b): Uranophane occurs as fracture filling associated with curite and fractured opaques (may be columbite \& thorite)

(Fig.5c): Perthite megacryst encloses euhedral zoned allanite crystal, fractured opaque crystal (may be thorite) and fracture filling of secondary uranophane.

(Fig.5d): Three monazite crystals show high interference color mantled with secondary allanite associated with perthite and quartz, the minerals are fractured and stained with iron oxides .

(Fig.5e): Fractured perthite and plagioclase stained with iron oxides, euhedral kasolite crystal, secondary fluorite and quartz.

(Fig.5f): Fractured perthite and plagioclase, secondary uranophane and hematitized pyrite.

(Fig.5g): Secondary minerals comprise fluorite, quartz, iron oxides, zircon occur as a cavity fillings .

(Fig.5h): High concentration of metamict zircon ( $\mathrm{Zr}$ ) with sieve texture, allanite (alnt), curite (curt), opaques (opq), and fluorite (flr). Mineralized sample 
brown, red, grey anhedral to subhedral prismatic crystals (Fig.5a). Fluorite occurs as colorless or yellow and violet crystals filling cavities and micro-fractures (Fig.5g). Violet fluorite crystals are found associated with zircon, allanite, curite and oaques in the mineralized samples (Fig.5h). $\boldsymbol{P y}$ rite occurs in all thin sections as euhedral cubic opaque crystals. Occasionally, pyrite encountered completely or partially altered to hematite and geotite (Fig.5f).

\section{RADIOELEMENTS POTENTIALIY}

Enrichment of uranium in later magmatic stages is due to the incompatible behavior of uranium in normal rock-forming minerals because of its large ionic radius and high charge as well as its low concentration in magma. Radioactivity is a natural phenomenon exhibited by rocks due to the presence of natural radioactive isotopes and their radioactive daughter products. Generally, the acidic igneous rocks represent the main source of uranium deposits whether they were of primary or secondary origin. $\mathrm{K}^{40}, \mathrm{U}^{238}$ and $\mathrm{Th}^{232}$ are the main radioactive isotopes distributed in the rocks. Uranium is the most mobile element compared to potassium and thorium. The variations of $U$ and Th contents with differentiation are reflected by variations of radioactivity in the rocks. Gamma Rays are used in field for identification of $\mathrm{K}, \mathrm{eU}$, eTh concentrations and derived ratios could be applied to base metal deposit alteration studies (Sikka, 1962, Moxham et al., 1965).

Several instruments such as UG-130 and PGR-500 were used for reconnaissance during radioactive survey of the studied area. On the other hand, an extensive ground gamma-ray spectrometric survey was carried out on the ex- posed granite dikes using $(103 \mathrm{~cm} 3)$ with higher density Bismuth Germanate Oxide (BGO) detector makes it also an ideal portable instrument for Potassic Alteration measurements.

The in situ gamma-ray spectrometry measurements are expressed in ppm for equivalent uranium (eU) and equivalent thorium (eTh) and in percent for potassium (K). Particular attention was paid to structural features such as contacts, shear zones and faults as well as hydrothermally altered zones. All measurements were taken on the rock surface. Table (1) summarizes the field measurements of $\mathrm{K} \%$, eU ppm and eTh ppm contents as well as the eU/eTh and eTh /eU ratios. Also the obtained data are represented as bar diagrams (Figs.6a, b, c \& d) for comparison between the radioactivity of the granite dikes and their related pegmatite and mineralized sites

The studied granite dikes are characterized by high contents of radioelements and show high thorium anomalies more than the uranium where average of eU is $106.3 \mathrm{ppm}$ while that of eTh is $466 \mathrm{ppm}$. The maximum eTh content exceeds $2523 \mathrm{ppm}$ while that of eU reaches 498 $\mathrm{ppm}$. The rock show a conspicuous low average eU/eTh ratio equal 0.26 and possess a considerably high eTh /eU ratio reach up 7.8 with average equal 4.18 .

The mineralized sites show very high level of radioactivity and contain high U- and Th-concentrations compared to the granite dikes and the pegmatites. In these zones eU and $\mathrm{eTh}$ contents reach up to $1386 \mathrm{ppm}$ and $7331 \mathrm{ppm}$ respectively with average contents equal $707.2 \mathrm{ppm}$ for $\mathrm{U}$ and $4044 \mathrm{ppm}$ for Th. On the other hand, the average values of eU/eTh ratios intensely decrease and eTh /eU ratios intensely increase

Table (1): Radiometric eU and eTh contents (ppm) and K\% in addition to eU/eTh and eTh/eU ratios.

\begin{tabular}{|c|c|c|c|c|c|c|c|c|c|c|c|c|c|c|c|c|}
\hline \multirow{2}{*}{ Type } & \multirow{2}{*}{ NO.* } & \multicolumn{3}{|c|}{$\mathrm{K} \%$} & \multicolumn{3}{|c|}{ eU (ppp) } & \multicolumn{3}{|c|}{ eTh (ppm) } & \multicolumn{3}{|c|}{ eU/eTh } & \multicolumn{3}{|c|}{$\mathrm{eTh} / \mathrm{eU}$} \\
\hline & & Max & Min & Av & Max & Min & Av & Max & Min & Av & Max & Min & Av & Max & Min & Av \\
\hline Gran & 125 & 18 & 2.6 & 6.56 & 48 & 25 & 106.3 & 2523 & 64 & 465.8 & 0.69 & 0.13 & 0.26 & 7.8 & 1.45 & 4.18 \\
\hline Min & 20 & 66.5 & 5 & 26.4 & 1386 & 197 & 707.2 & 7331 & 1298 & 4044 & 0.59 & 0.13 & 0.17 & 7.5 & 4.9 & 6.1 \\
\hline Peg & 7 & 8.6 & 1.4 & 5.1 & 10 & 4 & 6.6 & 3 & 8 & 16 & 0.6 & 0.28 & 0.43 & 3.5 & 1.7 & 2.47 \\
\hline $\begin{array}{l}\text { NO.* } \\
\text { Gran } \\
\text { Min = } \\
\text { Peg = }\end{array}$ & $\begin{array}{l}\text { er o } \\
\text { te d } \\
\text { lize } \\
\text { ites }\end{array}$ & nea & rem & & & & & & & & & & & & & \\
\hline
\end{tabular}




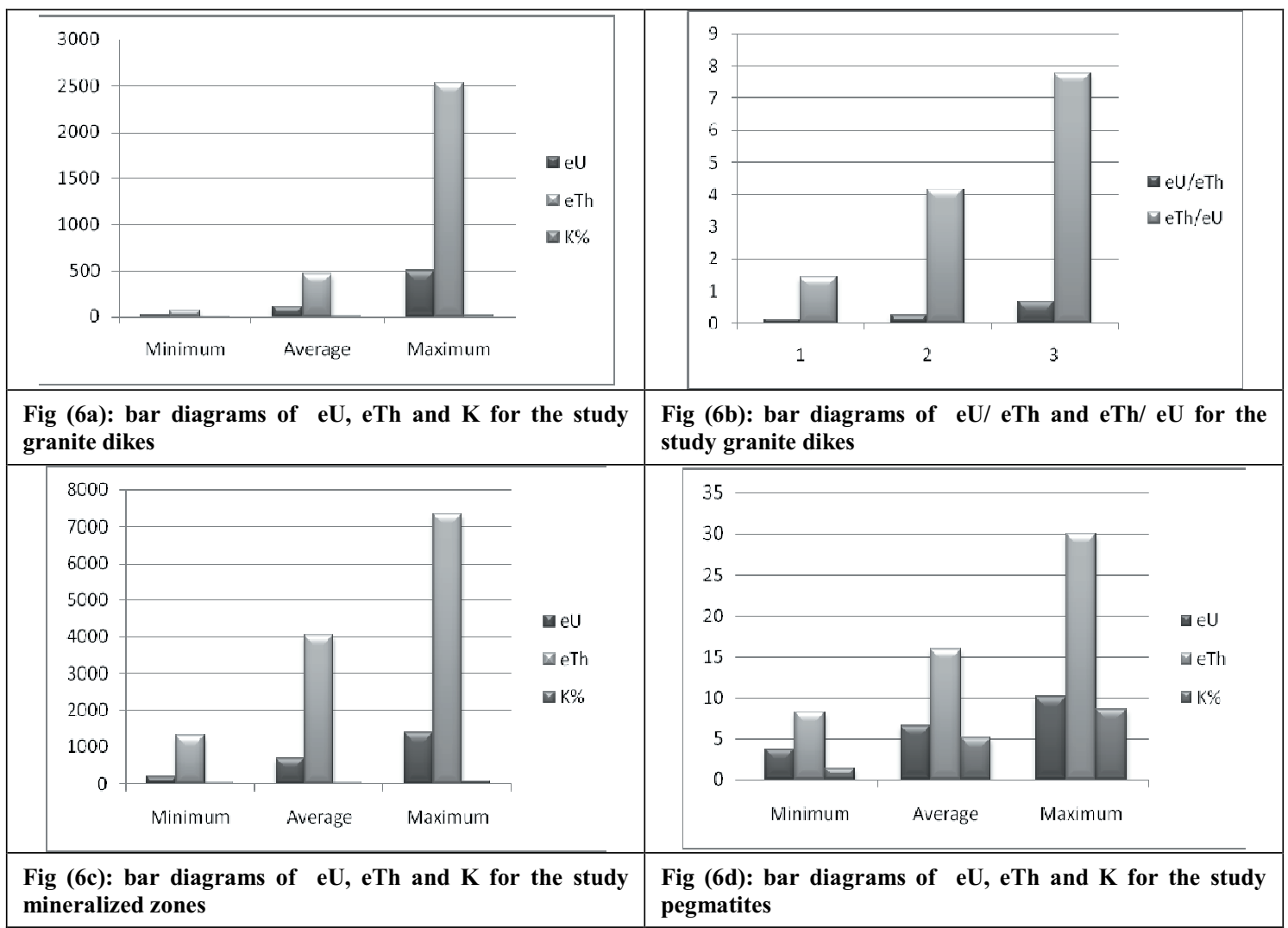

reaching 0.17 and 6.1 respectively. The pegmatites show the lowest level of radioactivity and possess lower eU and eTh contents do not exceed $10 \mathrm{ppm}$ and $30 \mathrm{ppm}$ with average contents $6.6 \mathrm{ppm}$ and $16 \mathrm{ppm}$ respectively.

Normally, thorium is three times as abundant as uranium in rocks (Rogers and Adams, 1969). When this ratio is disturbed, it indicates a depletion or enrichment of uranium. The studied granite dikes show eTh/eU average ratios equal 4.18 and reach up to 7.8 , suggesting uranium leaching (See table 1). The eU and eTh binary diagram of the studied granite dikes exhibits a wide range of variation. The plotted measurements mostly scattered around the lines eTh/eU $=5$ and eTh/ $\mathrm{eU}=4$ (Fig. 7). These reflect the clear increasing of the eTh value comparing to eU. The high content of eTh relative to $\mathrm{eU}$ in the granite dike reflect the greater mobility of $U$.

The equation eU-(eTh/3.5) reflects the uranium mobilization. If result of this equation equals zero, it indicates that no uranium mobilization took place. When it is greater than zero it means that uranium was enriched (added to rock) while the negative values mean uranium leached out. In this study most of the measurements (Fig.8) have been taken on the granite dikes show $\mathrm{eU}-(\mathrm{eTh} / 3.5)$ values lower than zero and sometimes reach up to -324, suggesting local U-leaching especially along kaolinized and/or highly fractured zones. Few samples show eU-(eTh/3.5) values above zero and sometimes reach up to 45 , especially in compact and undeformed parts.

With regard to the mineralized zones, result of the equation $\mathrm{eU}-(\mathrm{eTh} / 3.5)$ revealed that all the measurements lie under the zero line although all the eU ppm measurements are very high (see table 1). This means that these mineralized zones have been originated from a late magmatic phase of magma very rich in radioelements with thorium concentration more than uranium. In later time, these zones subjected to deformation and alteration processes led to uranium leaching. The granite dike itself has been subjected to the same processes. The mineralized zones are highly charged with iron oxides, thorite, monazite and zircon, suggesting origin from Th-rich hydrothermal solutions.

\section{MINERALOGY}

Mineralogical investigation of the mineral constituents of the samples was carried out by 


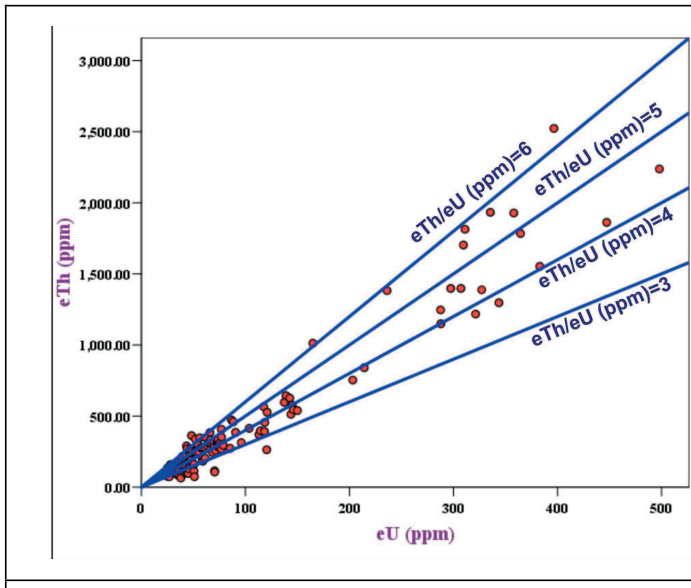

Fig (7): Binary diagram show eTh versus eU

using binocular stereomicroscope, X-ray diffraction technique. Semi quantitative EDX chemical analyses were also carried out using a Phillips XL-30 Environmental Scanning Electron Microscope (ESEM). All these analysis were carried out in the laboratories of the Nuclear Materials Authority (NMA), Egypt. The obtained minerals can be classified into:

1. Non radioactive minerals including magnetite, goetite, hematite, cronstedite, titanite, fluorite, pyrite and garnet (spessarite).

2. Uranium- and thorium- bearing minerals including zircon, colombite, samarskite and allanite,.-

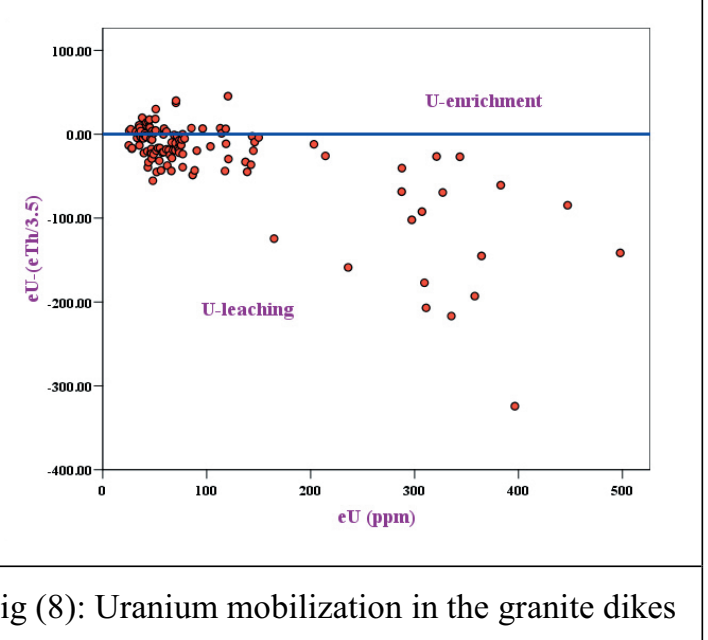

3. Thorium minerals including thorite

4. Uranium minerals including curite and uranophane

\section{Magnetite $\left(\mathrm{Fe}_{3} \mathrm{O}_{4}\right)$}

Magnetite represents the major part of opaque grains of the studied samples. It is black granular masses, and strongly magnetic,. It was separated by using small hand-magnet and thus subjected to XRD analysis. Magnetite is widespread in samples and increases in mineralized zones. The obtained XRD data for Magnetite is shown in (Fig.9a).

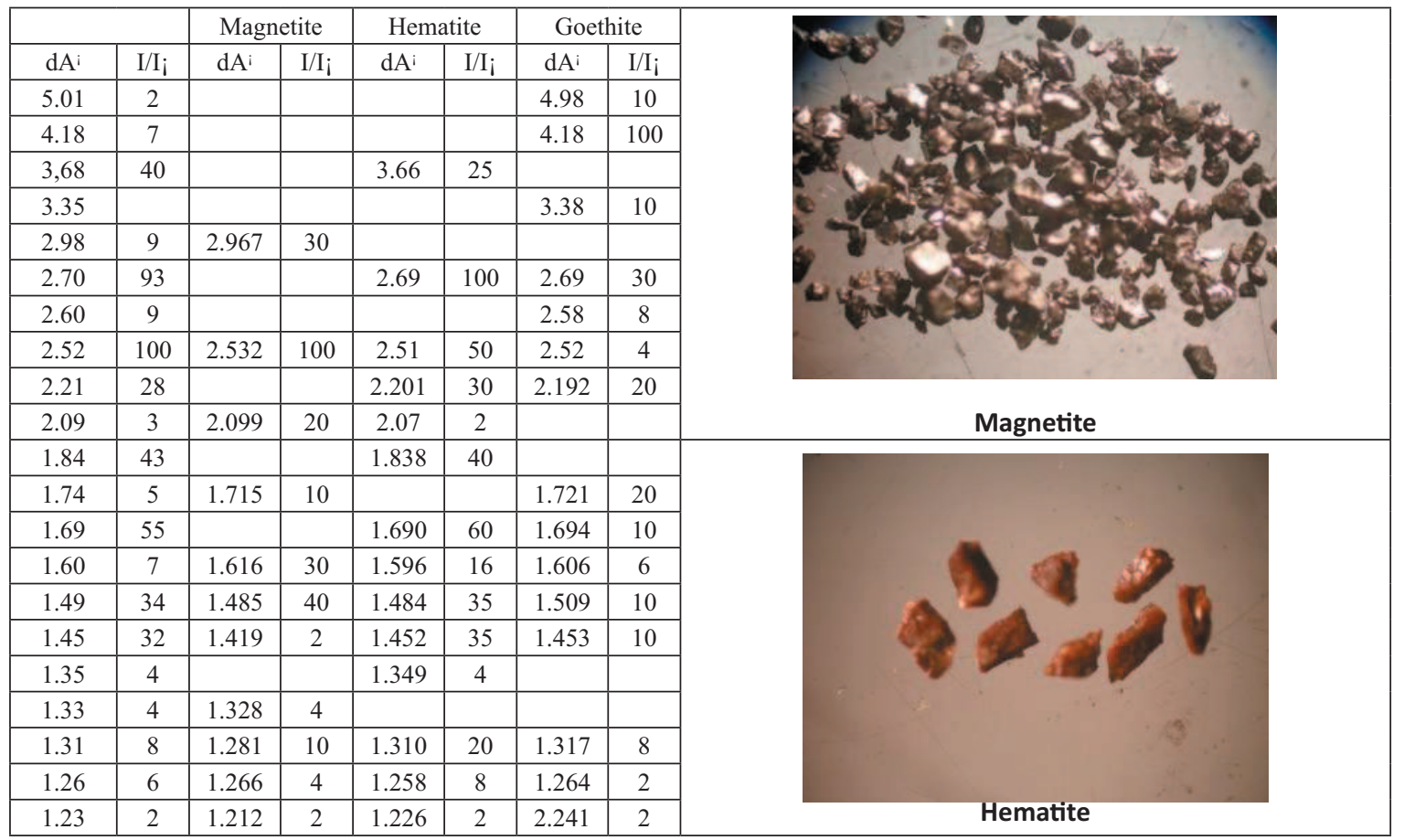

(Fig. 9): XRD data for magnetite, hematite and goetite 
Goethite $(\mathrm{FeO} . \mathrm{OH})$ - (Hematite $\left(\mathrm{Fe}_{2} \mathrm{O}_{3}\right)$.

Goethite and hematite are formed by the oxidation and hydration of iron minerals or as a direct precipitate. In the studied granite dikes, the oxidizing alkaline hydrothermal solutions percolating through the fracture system will deteriorate the $\mathrm{Fe}^{2+}$ bearing minerals, such as biotite and pyrite. Biotite converts into muscovite and iron hydroxides. The produced iron hydroxides solidify as goethite or may dehydrate into hematite. Also, goethite and hematite are produced as a result of the entirely oxidation of pyrite. The produced goethite-hematite imparts the altered granite with strong reddish brown hues. The obtained XRD data for hematite and goethite are shown in (Fig.9).

\section{Cronstedtite}

cronstedtite $\left[\mathrm{Fe}_{4}^{2+} \mathrm{Fe}_{2}^{3+}\left(\mathrm{Fe}_{2}{ }^{3+} \mathrm{Si}_{2}\right) \mathrm{O}_{10}(\mathrm{OH})_{8}\right]$ is black to brownish-black mineral consisting of a hydrous iron silicate crystallizing in hexagonal prisms. The obtained XRD data for cronstedtite is shown in (Fig.10).

\section{Titanite}

Titanite is monoclinic mineral of composition $\mathrm{CaTiSiO}_{5}$ but with some replacement of $\mathrm{O}$ by $\mathrm{OH}$ and $\mathrm{F}$. Titanite is a common accessory mineral in igneous rocks. The obtained XRD data for Titanite is shown in (Fig.10).

\section{Fluorite CaF2}

Fluorite occurs as transparent to translucent crystals that range in color from colorless to blue and purple. The purple color of the familiar variety blue john is due to the presence of colloidal calcium. The XRD data of fluorite is shown in (fig.10).

\section{Pyrite (FeS2)}

Pyrite occurs as octahedron crystals with palebrass yellow color and metallic luster. Pyrite is the predominant heavy minerals in the studied granite dikes and in some samples it reaches about $60 \%$ of them. Generally, the studied pyrite is fresh and occasionally partly or entirely oxidized to Fe-oxy-hydroxides such as hematite and goethite. This process can be classified as pseudomorphic desulphidization under oxidizing conditions. The oxidation of such pyrite had most probably motivated the reduction and fixation of uranium from the mineralizing solutions. The obtained XRD data for pyrite are shown in (Fig.11).

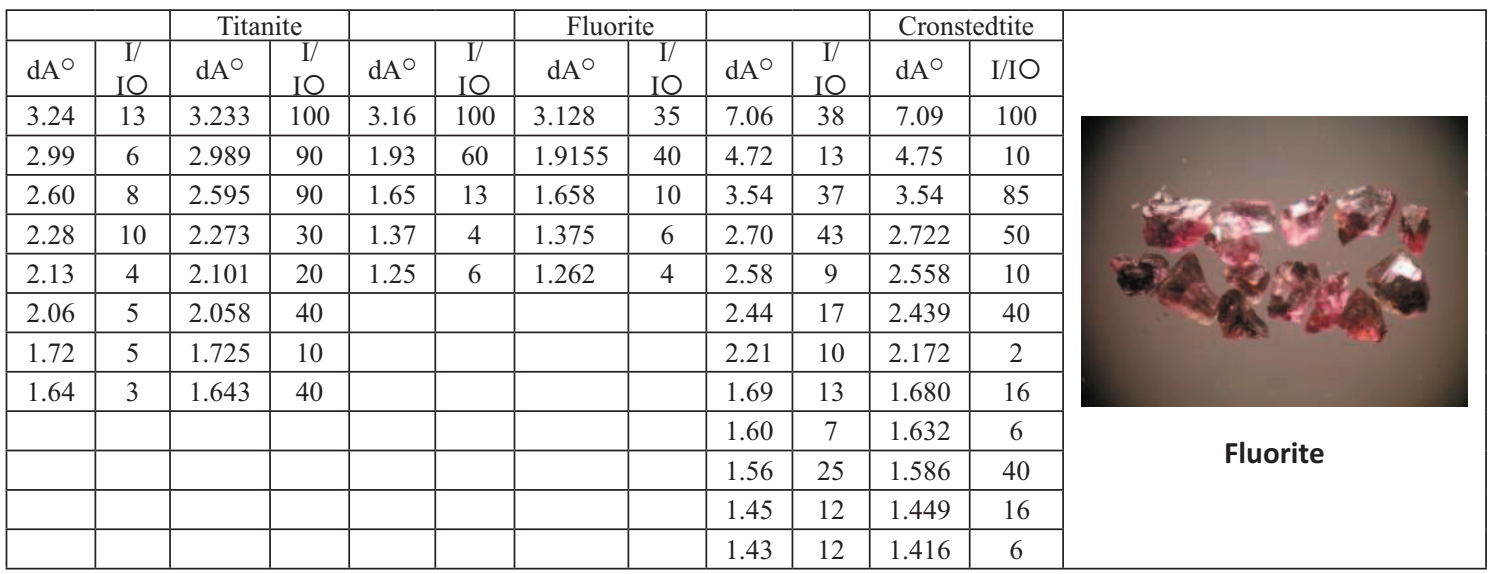

(Fig. 10): XRD data for titanite, fluorite and crostedtite

\begin{tabular}{|c|c|c|c|c|c|c|c|c|}
\hline & \multicolumn{2}{|c|}{ Pyrite } & \multirow[b]{2}{*}{$\mathrm{dA}^{\circ}$} & \multirow[b]{2}{*}{$\mathrm{I} / \mathrm{I} 。$} & \multicolumn{2}{|c|}{ Pyrite } & \\
\hline $\mathrm{dA}^{\circ}$ & $\mathrm{I} / \mathrm{I}$ 。 & $\mathrm{dA}^{\circ}$ & $\mathrm{I} / \mathrm{I}$ 。 & & & $\mathrm{dA}^{\circ}$ & $\mathrm{I} / \mathrm{I}$ 。 & \\
\hline 3.13 & 18 & 3.128 & 35 & 1.50 & 5 & 1.5025 & 20 & \\
\hline 2.71 & 79 & 2.709 & 85 & 1.45 & 18 & 1.4448 & 25 & \\
\hline 2.42 & 26 & 2.423 & 65 & 1.24 & 3 & 1.2427 & 12 & \\
\hline 2.21 & 31 & 2.2118 & 50 & 1.21 & 6 & 1.2113 & 14 & \\
\hline 1.92 & 24 & 1.9155 & 40 & & & & & \\
\hline 1.63 & 100 & 1.6332 & 100 & & & & & Pyrite \\
\hline
\end{tabular}

(Fig. 11): XRD data for pyrite 


\section{Curite $\left(\mathrm{Pb}_{2} \mathrm{U}_{5} \mathrm{O}_{17-} 4 \mathrm{H}_{2} \mathrm{O}\right)$}

Curite is an oxide mineral of uranium and lead. It is a common product of oxidation, dissolution and replacement of uraninite (Isobe et al. 1992, Finch 1994). The mineral is commonly associated with uranyl phosphate minerals, and several authors have proposed a genetic relation between these minerals (Frondel 1958, Deliens 1977, Finch \& Ewing 1992). Curite occurs as orange-red and reddish brown grains or as glassy anhedral crystals with reddish cast. Its XRD data is shown in (Fig.12).

\section{Zircon (ZrSiO4):}

Zircon is a common accessory mineral in a wide range of rocks, particularly in felsic igneous rocks (e.g. Heaman et al., 1990; Hoskin \& Schaltegger, 2003). The importance of this accessory mineral lies in a combination of factors, including its tendency to incorporate trace elements (including radionuclides), (Watson, 1996; Watson \& Cherniak, 1997). Although the abundance of zircon is low, it strongly affects the behavior of many trace elements during the crystallization of magmas, and understanding of its chemistry therefore is important for petrological modelling (e.g. Nagasawa, 1970; Watson, 1979; Murali et al., 1983).

The studied zircon occurs as pale to dark brown massive compact grains that are generally translucent to opaque. The most common habit is the bipyramidal form with various pyramidal faces and outgrowths. Some zircon crystals are however characterized by extremely short prisms and are more or less equidimensional and exhibiting square cross section. It is referred to the pyramidal combination with extremely short prisms as mud zircon (El-Gemm izi, 1984) and to the prismatic type with no tendency to be elongated as murky type (Williams et al., 1956). Some grains show secondary growths, multiple growth and fused aggregations. Some crystals are characterized by sieve texture due to inclusions of other minerals especially radioactive ones. The XRD data of zircon is shown in (fig.13). The Semi quantitative analyses (EDX) of zircon identify the presence of thorite inclusions (fig.14).

\section{Garnet (spessartite - $\mathrm{Mn}_{3} \mathrm{Al}_{2} \mathrm{Si}_{3} \mathrm{O}_{12}$ )}

A member of a group of cubic minerals with a general formula $\mathrm{R}_{3} 2+\mathrm{R}_{2} 3+\mathrm{Si}_{3} \mathrm{O}_{12}$ where the divalent metals are magnesium, iron, manganese, or calcium and the trivalent metals are aluminum, iron, or chromium. Garnets are divided into two series, pyralspite (pyrope, almandine, spessartite) and ugrandite (uvarovite, grossular, andradite). Garnets commonly develop dodecahedral and icositetrahedral forms and show variety of colors. Pyralspite garnets are typically pink, red, or brown.

Garnet occurs as reddish-brown transparent to translucent massive grains of granular form, possessing vitreous luster and being usually hard. The XRD data of spessartite is shown in (fig.13).

\section{Thorite (ThSiO4)}

Thorite is the most common mineral of thorium and it is currently an important ore of uranium. Thorite represents the main radioactive mineral identified in the studied rock. It is very common in all samples and has a considerable concentration particularly in the mineralized zone. Thorite occurs as well developed cubic crystals or as granular form with black to brownish black color. Also, thorite grains were also detected included within zircon crystals by using EDX technique (Fig.14).

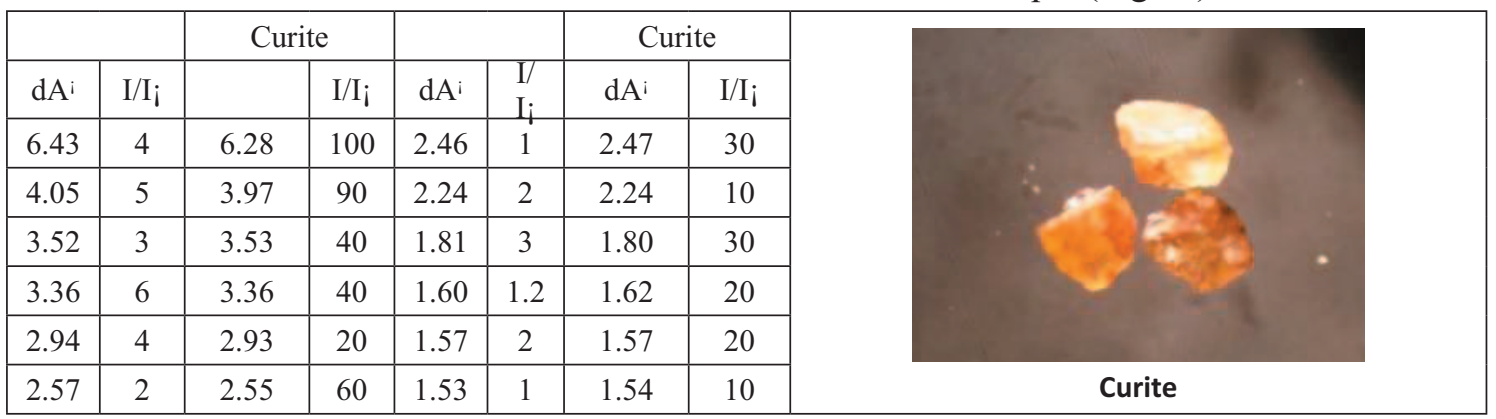

(Fig. 12): XRD data for curite 


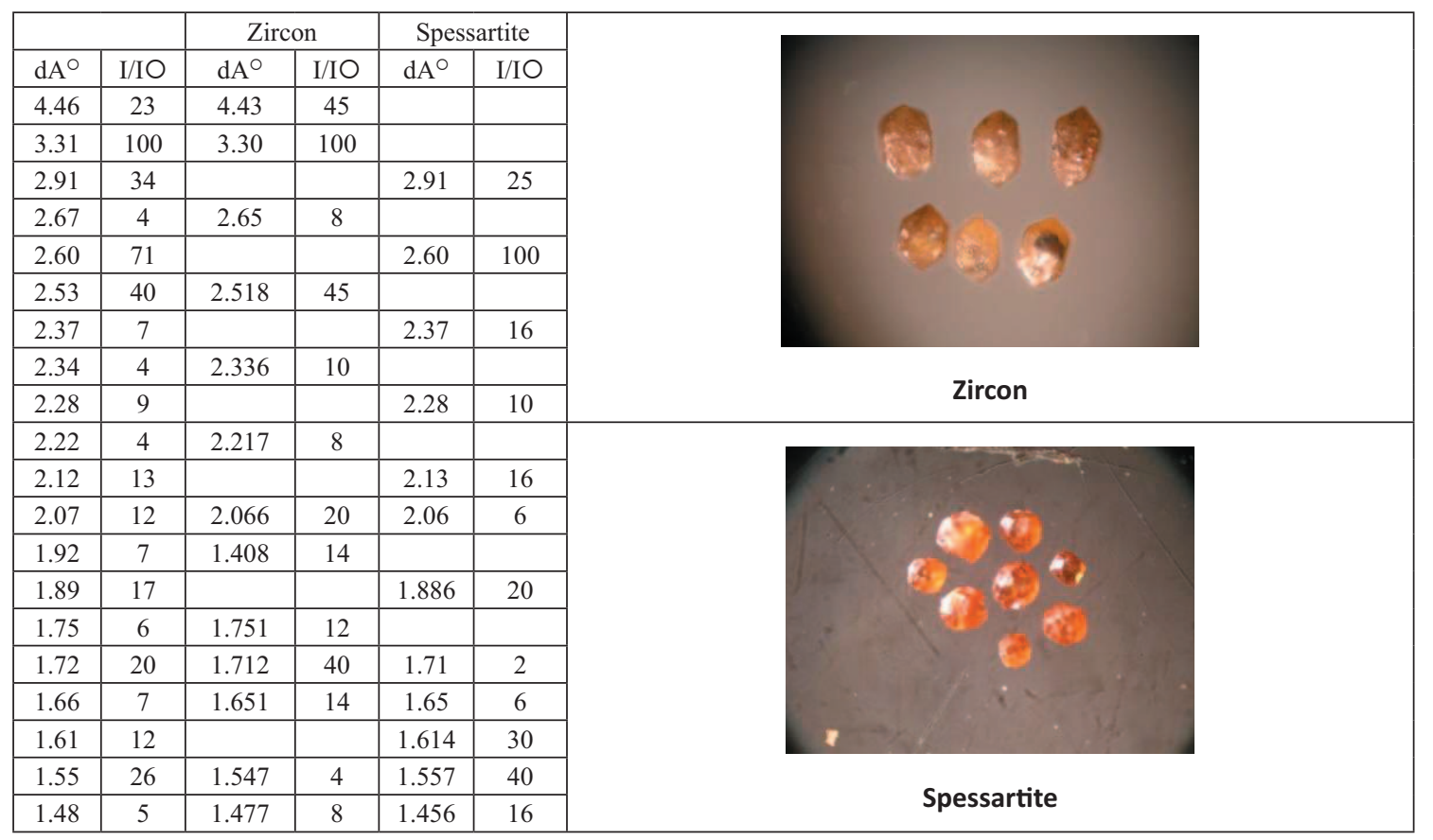

(Fig. 13): XRD data for zircon and spessartite.

\section{Uranophane}

Under binocular microscope, uranophane grains are found generally as to be massive with a granular form, and their luster is dull and greasy. These grains are distinguished by their bright canary to lemon yellow colors. Also, uranophane occurs as thin film coating cracks and fracture surfaces of quartz mixed with iron oxides. The EDX data of the studied uranophane is illustrates in (Fig. 14).

\section{Columbite (FeNb2O6):}

The columbite group of minerals comprises a large number of structurally related orthorhombic $\mathrm{AB}_{2} \mathrm{O}_{6}$ compounds $(\mathrm{B}=\mathrm{Ta}, \mathrm{Nb})$. The columbite subgroup is $\mathrm{Nb}$-dominant, and the tantalite subgroup is Ta-dominant. They contain $\mathrm{U}$ and $\mathrm{Th}$ in various amounts and are commonly metamict but none has been described with $U$ as essential constituent. The relatively small octahedral A-site is commonly occupied by $\mathrm{Mg}^{2+}$ (magnesiocolumbite) and transition-metal cations such as $\mathrm{Fe}^{2+}$ (ferrocolumbite) and $\mathrm{Mn}^{2+}$ (manganocolumbite), while $U$ and Th substitutions are relatively minor. Columbite is detected in all the studied samples. It is generally black in colour and possess a brilliant metallic luster and occurs as irregular elongated angular grains with sharp edges. Pure columbite grains were prepared and detected using EDX technique (Fig.14).

\section{Samarskite:}

Samarskite is a group of the Nb-Ta mineral varieties having the general formula $\mathrm{AmBnO}_{2}(\mathrm{~m}+\mathrm{n})$ where A represents $\mathrm{Fe} 2+, \mathrm{Ca}$, REE, Y, $\mathrm{U}$ and Th while $\mathrm{B}$ represents $\mathrm{Nb}, \mathrm{Ta}$ and Ti. Hanson et al. (1999), proposed a nomenclature for the samarskite group of minerals based on their classification into three species. Thus, if the REE $+\mathrm{Y}$ are the dominant, the name samarskite-(REE+Y) should be used with the dominant of these cations as a suffix. If $\mathrm{U}+\mathrm{Th}$ are the dominant, the mineral is properly named ishikawaite whereas if $\mathrm{Ca}$ is the dominant cation, the mineral should be named calciosamarskite. Recently, samarskite-( $\mathrm{Yb}$ ) has been identified as a new species of the samarskite group (Simmons et al. 2006).

Under the binocular microscope, samarskite is usually found in appreciable amounts and distributed in all size fractions with a tendency to increase with decreasing grain size. The defined samarskite crystals are generally massive with granular form and having a characteristic vitreous luster. These crystals are generally translucent, compact, and hard. They are mainly velvetreddish brown to bloody red in color. Although most crystals often possess granular form, how- 


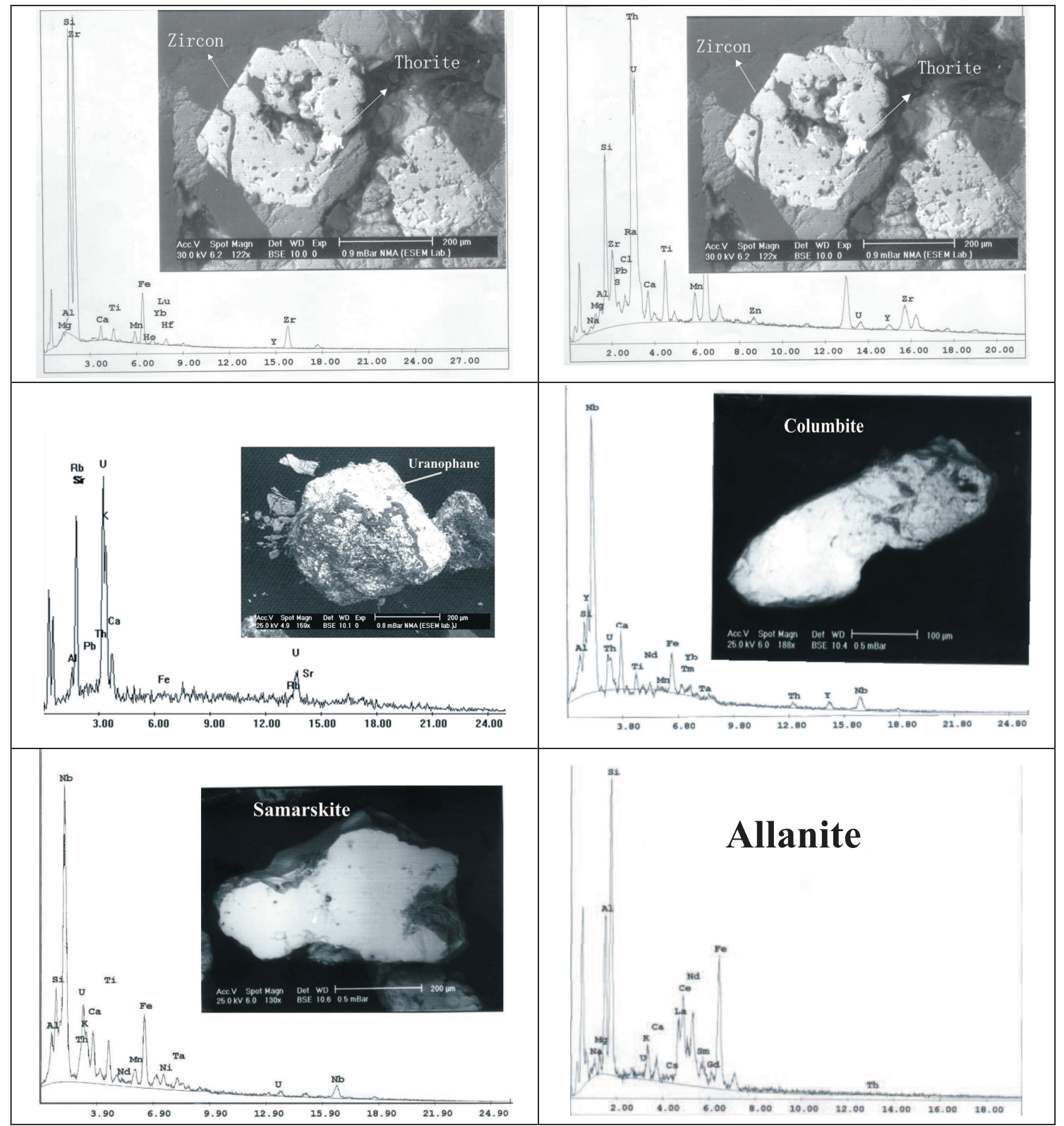

(Fig. 14): EDX and BSE of zircon, thorite, uranophane, columbite, samarskite and allanite.

ever, some crystals are present as massive rodlike and tabular crystals. Pure samarskite grains were separated and detected using EDX technique (Fig.14).

Allanite $\left[(\mathrm{Ce}, \mathrm{Ca}, \mathrm{Y})(\mathrm{Al}, \mathrm{Fe})_{3}\left(\mathrm{SiO}_{4}\right)_{3}(\mathrm{OH})\right]$

Allanite (orthite) is a member of epidote group that contain a significant amount of rare earth elements reach up to $20 \%$. Also, a large amount of additional elements, including $\mathrm{Th}, \mathrm{U}, \mathrm{Zr}, \mathrm{P}, \mathrm{Ba}, \mathrm{Cr}$ and others may be present in the mineral. It is occur as grains and rod-like crystals with brown and occasionally black color, often coated with a yellow-brown alteration product, likely limonite. It is occur in a considerable amount especially in the mineralized zone. Pure allanite grains were separated and detected using EDX technique (Fig.14).

(Fig. 14): EDX and BSE of zircon, thorite, uranophane, columbite, samarskite and allanite.

\section{TRACE ELEMENTS POTENTIALITY}

Chemical analyses were done for seven samples representing the granite dikes and their mineralized zones for some of trace elements by using XRF technique. The same samples were studied petrographically and mineralogically. 
The results of these analyses are illustrate bellow (Fig.15). The results revealed high concentration of $\mathrm{Zr}, \mathrm{Y}, \mathrm{Nb}, \mathrm{Ba}, \mathrm{Zn}, \mathrm{Rb}$ and $\mathrm{Pb}$ elements. These results are in a good harmony with the petrographical and mineralogical studies which confirm presence of considerable amounts of zircon, xenotime YPO4, allanite ( $\mathrm{Ce}, \mathrm{Ca}, \mathrm{Y}) 2(\mathrm{Al}$, $\mathrm{Fe}+++3(\mathrm{SiO} 4) 3(\mathrm{OH})$, Samarskite $(\mathrm{Yb}, \mathrm{Y}$, $\mathrm{REE}, \mathrm{U}, \mathrm{Th}, \mathrm{Ca}, \mathrm{Fe}++)$, columbite ( $\mathrm{Nb}, \mathrm{Ta}$, $\mathrm{Ti}_{4} \mathrm{O}_{4}$, kasolite $\mathrm{Pb}(\mathrm{UO} 2) \mathrm{SiO}_{4}$, uranophane, curite, thorite and garnet minerals which posses these elements. On the other hand, chemical analyses were done for five samples to determine $\mathrm{U}, \mathrm{Au}$ and Pt elements. The results are illustrate in figure (16).

\section{CONCLUSION}

The studied microgranite dikes contain anomalously high $\mathrm{U}$ and $\mathrm{Th}$. U and Th occur as uranophane, curite and thorite minerals. Most of the uranium presents in these dikes is concentrated in many minor or accessory minerals: $\mathrm{Zr} / \mathrm{Ti}$ rich inclusions, samarskite, xenotime, zircon, monazite, titanite, allanite and apatite

Average $\mathrm{U}$ and $\mathrm{Th}$ contents determined from 125 spectrometric measurements are $106.3 \mathrm{ppm}$ $\mathrm{eU}$ and $465.8 \mathrm{ppm}$ eTh respectively with a eU/ eTh ratio of 0.26 . Th is more evenly distributed than U, possibly because of the greater mobility of the latter. Areas of highest $U$ and Th are generally associated with the highly fractured, sheared and altered parts.

These rocks are intensely subjected to deformation and alteration processes led to rock fracturing, conversion of some rock forming minerals and the formation of new secondary minerals. The conversion of rock forming minerals is represented by clay minerals after feldspars, goethite and hematite after magnetite, biotite, hornblende

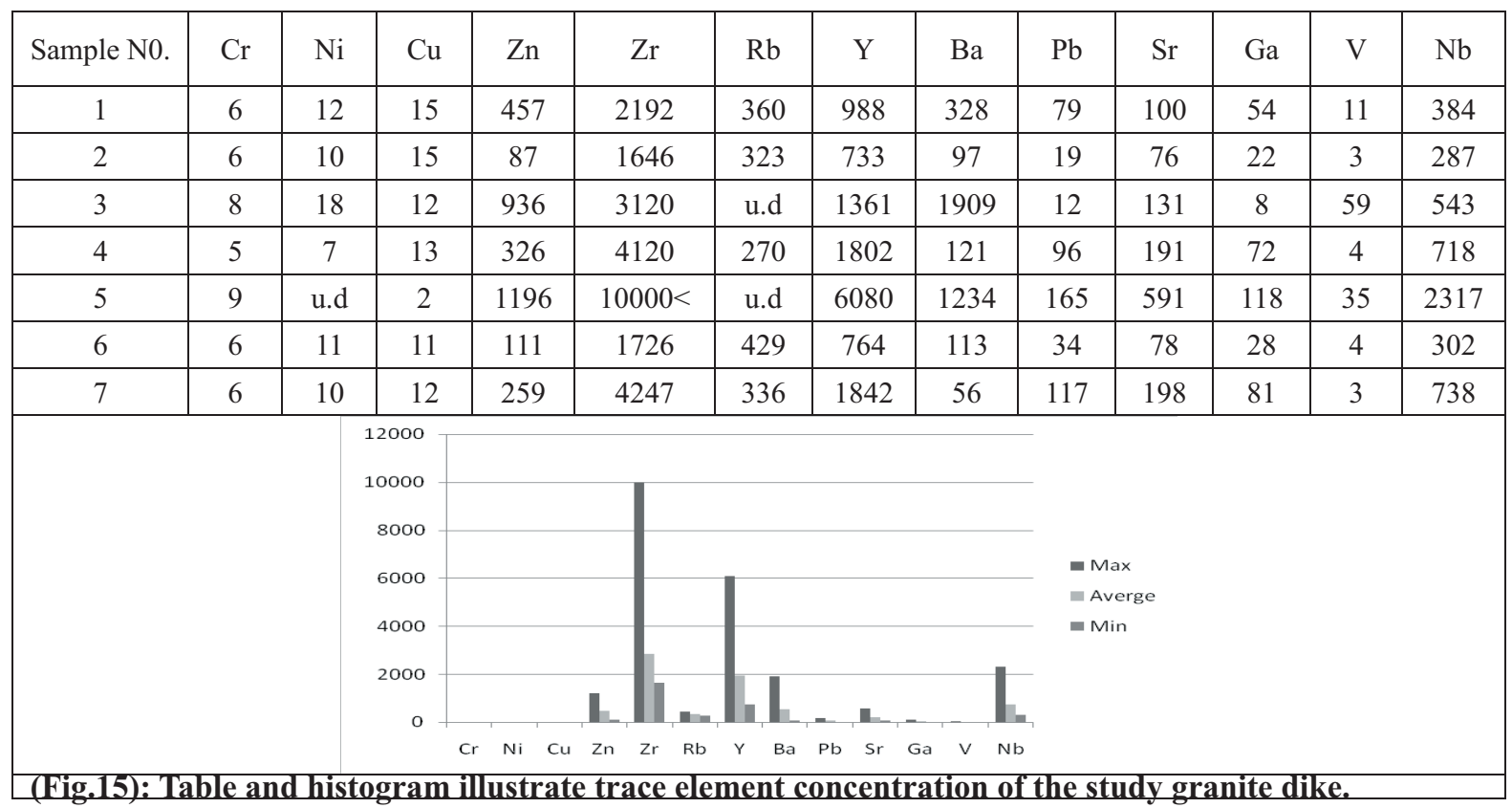

\begin{tabular}{|c|c|c|c|}
\hline Sample No. & $\mathrm{U}(\mathrm{ppm})$ & $\mathrm{Au}(\mathrm{ppm})$ & $\mathrm{Pt}(\mathrm{ppm})$ \\
\hline 1 & 190 & 2.272 & 34.96 \\
\hline 2 & 178.4 & 0.25 & 106 \\
\hline 3 & 352.5 & 0.264 & 7.6 \\
\hline 4 & 748 & $\mathrm{ND}$ & 10 \\
\hline 5 & 1019.2 & 1.696 & 39.36 \\
\hline Max & 1019.2 & 2.272 & 106 \\
\hline Averge & 497.62 & 1.1205 & 39.584 \\
\hline Min & 178.4 & 0.25 & 7.6 \\
\hline
\end{tabular}

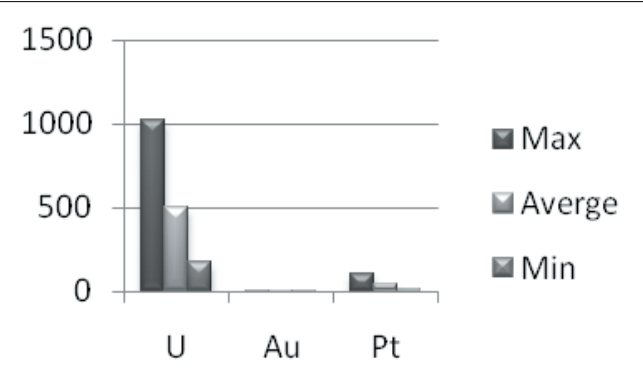

(Fig.16): Table and histogram illustrate the concentration of U, Au and Pt. 
and iron bearing sulfides (pyrite). The secondary minerals are represented by quartz, calcite and fluorite in addition to several radioactive minerals in the form of thin veinlets or fracture fillings as well as disseminations

Fractures plying a very important role in alteration processes which cause minerals conversion and formation as they provide suitable pass way for hydrothermal solutions and heated meteoric water that cause transformation processes and mobility of combatable elements.

Although uranium may occur in accessory minerals at the present level of erosion, such intrusions may represent the eroded root zones of mineralized dikes, the uranium having leached out during erosion and may be concentrated in adjacent sedimentary basins or elsewhere. Also, the leached uranium may represent the main source of uranium that added the highly radioactive ferruginated zones. Moreover, metamictization of uraniferous accessory minerals, such as zircon and monazite, would also provide large volume sources of uranium for leaching.

Uranium is transported by meteoric water, superheated solutions and hydrothermal fluids as soluble carbonate and fluoride complexes as indicated from the occurrence of calcite veinlets cutting the host rock and violet secondary fluorite dissemination at most alteration zones. The nature of uranyl ions may also help in uranium transportation particularly when the $\mathrm{pH}$ of the fluids is relatively low (Langmuir, 1978).

The presence of the iron oxy-hydroxides alteration, which is the main alteration process, played an important role in uranium enrichment. The iron oxides have a high ability to adsorbing uranium from its bearing solution (Hussein et al., 1965) and/or the prevalence of oxidation conditions and complex ions cause precipitation of uranium as complex uranyl ions (Cuney, $\underline{2003}$ ). It is apparent that the granite dikes were undergoing a long period of alteration and rockfluid interaction, providing the source for the formation of the secondary uranium minerals on the highly ferruginated and mineralized zones.

\section{REFFERENCES}

Banks, D. A., Yardely, B. W., Campbell, A. R. and Jarvis, K.
E. (1994): REE composition of an aqueous magmatic fluid: a fluid inclusion study from the Capitan Pluton, New Mexico. Chem. Geol. 113, 259-272.

Casas, I., Casabona, D., Duro, L., Depablo, J. (1994): The influence of hematite on the sorption of uranium (VI) onto granite filling fractures. Chem. Geol. 113, 319326.

Cathelineau, M. and Poty, B. (1989): U-Th-REE mobility in granitic environments at the hydrothermal stage. Metallogenesis of Uranium Deposits, IAEATC-542/6, Vienna, 63-77.

Cuney, M., (2003): Mechanisms of U-Fractionation. U solubility controls in silicate melts and fluid phase, partial melting and fractional crystallization. IAEA short course.

Dawson, K. R . (1956): Petrology and red colouration of wall-rocks, radioactive deposits, Goldfi elds Region, Sask . Geol. Surv. Can. Bull. , 33 , 1-46

Deliens , M. (1977): Associations de minéraux secondaires d'uranium à Shinkolobwe (région du Shaba, Zaire. Bull. Minéral. 100, 32-38.

Drot, R., Roques, J., Simoni, E. (2007): Molecular approach of the uranyl/mineral interfacial phenomena. C. R. Chimie 10, 1078-1091.

El Gemmizi. M. A. (1984): On the occurrence and genesis of mud zircon in the radioactive psammatic gneiss of Wadi Nugrus, Eastern Desert, Egypt. J. Univ. Kuwait. Sci., V. 11, 285-294.

EL Hadary A,. El Azab A., Omran A.A. (2015): Contributions to the geology and mineralogy of wadi Ras Abda area, North Eastern Desert, Egypt. Nuclear Sciences Scientific Journal. V. 2.

Finch, R.J. (1994): Paragenesis and Crystal Chemistry of the Uranyl Oxide Hydrates. Ph.D. thesis, Univ. of New Mexico, Albuquerque, New Mexico.

Finch, R.J. \& E wing, R.C. (1992): The corrosion of uraninite under oxidizing conditions. J. Nucl. Mater. 190, 133-156.

Frondel, C. (1958): Systematic mineralogy of uranium and thorium. U.S. Geol. Surv., Bull. 1064.

Hanson S.L., Simons W.B., Falster A.U., Foord E.E., Lichte F.E. (1999): Proposed nomenclature for samarskitegroup minerals: new data on ishikawaite and calciosamarskite, Mineral. Mag., 63, 27-63.

Heaman, L. M., Bowins, R. \& Crocket, J. (1990): The chemical composition of igneous zircon suites: implications for geochemical tracer studies. Geochimica et Cosmochimica Acta 54, 1597-1607.

Hoskin, P. W. O. \& Schaltegger, U. (2003): The composition of zircon and igneous and metamorphic petrogenesis. In: Hanchar, J. M. \& Hoskin, P.W.O. (eds) Zircon. Reviews in Mineralogy and Geochemistry 53, 27-62. 
Hussein, H. A., Faris, M. I. and Makram, W. (1965): Radioactivity of some accessory minerals especially zircon in some Egyptian granites and pegmatites. J. Geol., U. A. R., 9, no. 2: p. 13-16.

Isobe, H., Mur akami, T . \& E wing, R.C. (1992): Alteration of uranium minerals in the Koongarra deposit, Australia: unweathered zone. J. Nucl. Mater. 190, 174-187.

Kamineni, D.C., Chung, C.F., Dugal, J.J.B., Ejeckam, R.B. (1986): Distribution of uranium and thorium in core samples from the Underground Research Laboratory lease area, southeastern Manitoba, Canada. Chemical Geology 54, 97-111.

Langmuir, D. (1978): Uranium solution-mineral equilibria at low temperatures with applications to sedimentary ore deposits. Geochim. Cosmochim. Acta 42, p. 547569.

Moxham, R. M., Foot, R. S. and Bunker, C. M. (1965): Gamma ray spectrometer studies of hydrothermally altered rocks; Economic Geology, Vol. 60, p. 653-671.

Murali, A. V., Parthasarathy, R., Mahadevan, T. M. \& Sankar Das, M. (1983): Trace element characteristics, REE patterns and partition coefficients of zircons from different geological environments-a case study on Indian zircons. Geochimica et Cosmochimica Acta 47, 2047-2052.

Nagasawa, H. (1970): Rare earth concentrations in zircon and apatite and their host dacites and granites. Earth and Planetary Science Letters 9, 359-364.

Omran A. A. (2005): Geological, petrochemical studies and potentiality of uranium-thorium occurrences in Gabal Um Taghir El-Tahtani area with emphasis on the granitic rocks, Central Eastern Desert, Egypt. Ph.D. thesis, Ain Shams Univ., Cairo, Egypt. 189 p.

Rogers, J.J.W. and Adams, J.S.S. (1969): Uranium. In: Wedepohl, K. H. (ed.) Handbook of geochemistry, New York, Springer-Verlag, vol. 4, p. 92 B1- 92 C10.

Schürmann, H. M. E. (1966): The precambrian of the Gulf of Suez and the northern part of the Red Sea. E. J. Brill, Leiden. Netherland, $404 \mathrm{p}$.

Sikka, D. B. (1962): Aero-gamma ray spectrometer aids in the detection of faults; Research Bulletin of the Panjab University, Vol. 13, Parts 1-11, p. 91-102.

Simmons W.B., Hanson S.L., Falster A.U., (2006): Samarskite-Yb: a new species of the samarskite group from the Little Patsy pegmatites, Jefferson County, Colorado, Canadian Mineralogist, 44(5), 1119-1125.

Watson, E. B. (1979): Zircon saturation in felsic liquids: experimental results and applications to trace element geochemistry. Contributions to Mineralogy and Petrology 70, 407-419.

Watson, E. B. (1996): Dissolution, growth and survival of zircons during crustal fusion: kinetic principles, geological models and implications for isotopic inheritance. Transactions of the Royal Society of Edinburgh: Earth Sciences 87, 43-56.

Watson, E. B. \& Cherniak, D. J. (1997): Oxygen diffusion in zircon. Earth and Planetary Science Letters 148, $527-544$

Williams, F. A. Meehan, J.A. Paulo, K. L. John, T. U. and Rushton, H.G.: (1956):Economic geology of the decomposed columbite- bearing granite, Jos Plateau, Nigeria. Econ.Geol. 51: 303-32. 


\section{جيولوجية، تمعدنية و إمكانية تواجد العناصر المشعة فى الجدد الجرانيتية الدقيقة

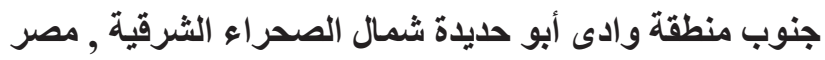 \\ على أحمد عمران}

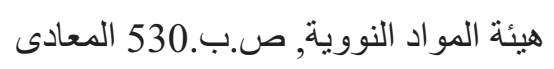

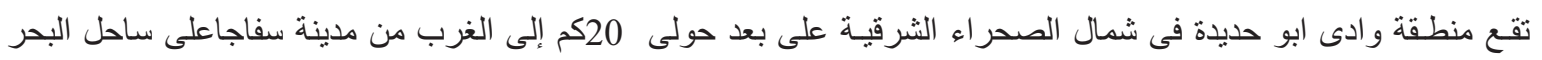

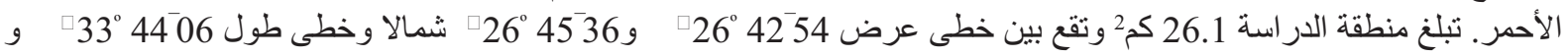

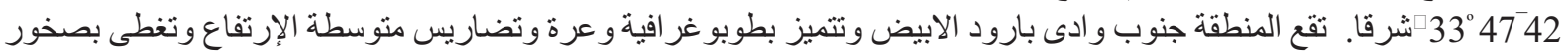

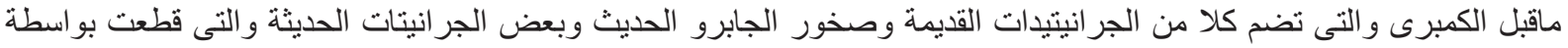

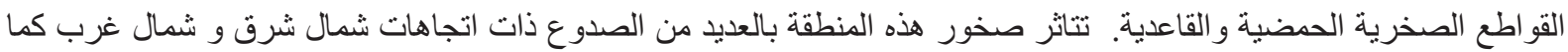

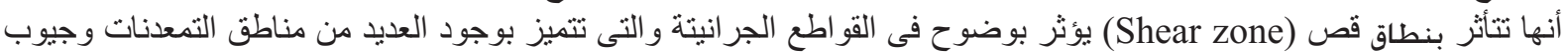

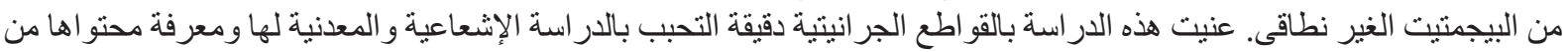

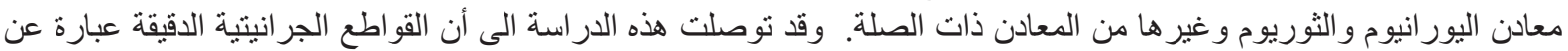

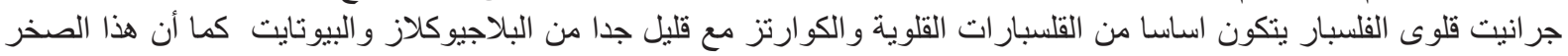

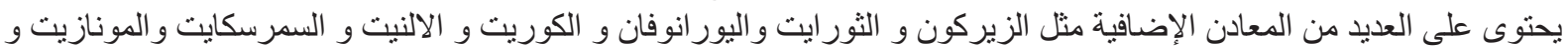

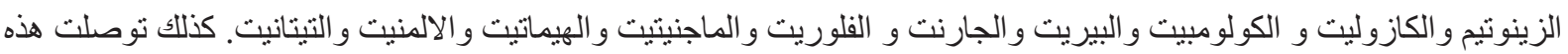

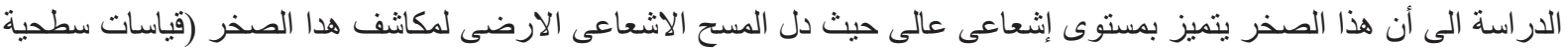

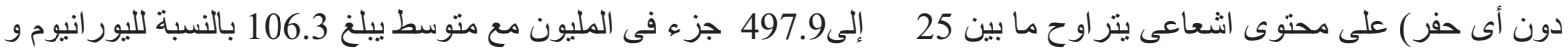

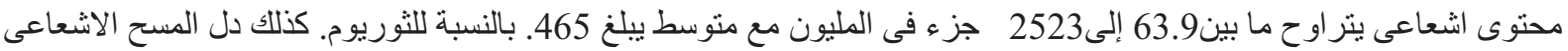

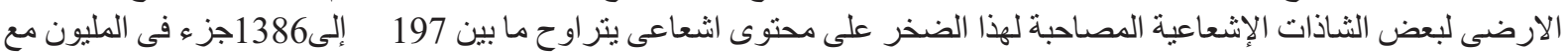

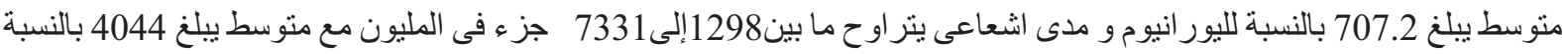

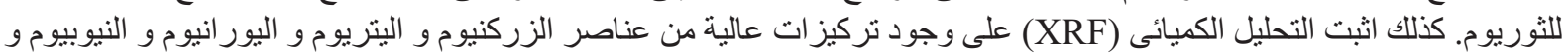

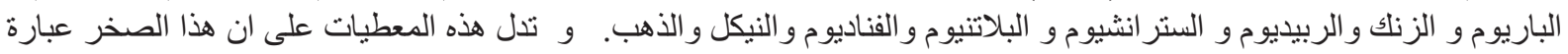

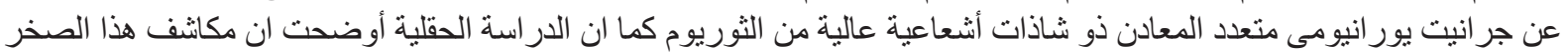

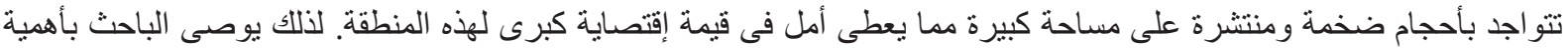

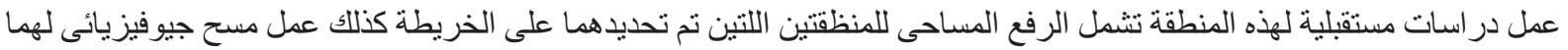
بالإضافة للار اسات الجيوكميائية و المعدنية للوصول الى تقييم دقيق لهيق لهذه الصخر. 